\title{
Increased responsiveness to methacholine and histamine after challenge with ultrasonically nebulised water in asthmatic subjects
}

\author{
JL BLACK, RE SCHOEFFEL, R SUNDRUM, N BEREND, SD ANDERSON
}

From the Departments of Pharmacology and Medicine, University of Sydney, and the Department of Thoracic Medicine, Royal Prince Alfred Hospital, Sydney, New South Wales, Australia

ABSTRACT Responsiveness to inhaled methacholine was compared before and 40-60 minutes after a challenge with ultrasonically nebulised water $\left(\mathrm{UNH}_{2} \mathrm{O}\right)$ in 16 asthmatic patients. The sensitivity to methacholine increased after $\mathrm{UNH}_{2} \mathrm{O}$ challenge $(\mathrm{p}<0.001)$. The mean dose of methacholine producing a $20 \%$ fall in forced expiratory volume in one second was 0.4 (95\% confidence limits $0.2,0.8) \mu \mathrm{mol}$, compared with $0.9(95 \%$ confidence limits $0.5,1.6) \mu \mathrm{mol}$ in the first methacholine challenge. When the study was repeated in six asthmatic patients with histamine substituted for methacholine, five of the patients were significantly more sensitive to histamine after $\mathrm{UNH}_{2} \mathrm{O}$ challenge. It is concluded that challenge with $\mathrm{UNH}_{2} \mathrm{O}$ produces an increase in airway responsiveness.

Asthmatic subjects develop bronchoconstriction in response to ultrasonically nebulised hypo-osmolar and hyperosmolar solutions. ${ }^{2}$ Anderson et al ${ }^{2}$ reported that the inhalation of up to $24 \mathrm{ml}$ of ultrasonically nebulised water $\left(\mathrm{UNH}_{2} \mathrm{O}\right)$ induced a reduction in the forced expiratory volume in one second $\left(F V_{1}\right)$ greater than $20 \%$ of the prechallenge level in 70 patients with asthma and that $56 \mathrm{ml}$ of water failed to produce any such reaction in nonasthmatic individuals. ${ }^{3}$ Although the mechanism by which $\mathrm{UNH}_{2} \mathrm{O}$ produces bronchoconstriction is unknown, the airway response in asthmatics to both exercise and $\mathrm{UNH}_{2} \mathrm{O}$ has been shown to be associated with a rise in neutrophil chemotactic activity in serum. ${ }^{45}$

In a series of experiments in rabbits, Irvin et al investigated the effects of the inflammatory response on histamine induced increases in airway resistance. Cumulative dose-response curves for histamine were obtained in anaesthetised animals before and after the administration of C5a desarg, a serum derived chemoattractant for neutrophils. The sensitivity to histamine increased after C5a desarg administration. When histological sections of these rabbit airways were examined, there was a florid

Address for reprint requests: Dr JL Black, Department of Pharmacology, University of Sydney, NSW 2006, Australia.

Accepted 14 January 1985 accumulation of neutrophils both in airway epithelium and in and around the smooth muscle.

We reasoned that if $\mathrm{UNH}_{2} \mathrm{O}$ challenge is associated with an increase in neutrophil chemotaxis bronchoactive substances may be produced by the attracted neutrophils, leading to a change in sensitivity of the bronchial smooth muscle. If this were so, $\mathrm{UNH}_{2} \mathrm{O}$ challenge might be expected to potentiate the response to bronchoconstricting agonists such as methacholine and histamine. In addition, if $\mathrm{UNH}_{2} \mathrm{O}$ challenge is associated with an acute inflammatory response, this in turn could alter epithelial permeability, allowing greater access of methacholine and histamine to smoth muscle receptor sites. This study investigates the effect of a prior challenge with $\mathrm{UNH}_{2} \mathrm{O}$ on the bronchoconstrictor response to methacholine and histamine in asthmatic patients.

\section{Methods}

We studied 22 asthmatic patients whose reversible airways obstruction had been confirmed during a visit to the respiratory laboratory at Royal Prince Alfred Hospital and who agreed to return for subsequent visits. The study protocol was approved by the ethics review committee, and all patients agreed to withhold medications for four to six hours before the challenge procedures. Details of the patients and 
Table 1 Details of patients, their maintenance treatment, and predicted normal values for FEV

\begin{tabular}{lllll}
\hline $\begin{array}{l}\text { Patient } \\
\text { No }\end{array}$ & Sex & Age & Treatment & $\begin{array}{l}\text { Pred } \\
\text { FEV },\end{array}$ \\
\hline 1 & M & 29 & S, B & 3.69 \\
2 & F & 22 & P, S, B, I, T & 3.03 \\
3 & F & 23 & S, B , & 3.34 \\
4 & M & 36 & F, B, C & 3.52 \\
5 & M & 43 & S, T & 3.13 \\
6 & F & 36 & S, B & 2.27 \\
7 & F & 22 & S & 2.73 \\
8 & F & 23 & S, B & 3.05 \\
9 & F & 38 & S, B & 2.40 \\
10 & M & 22 & S, B & 4.99 \\
11 & M & 39 & S, T & 3.50 \\
12 & F & 42 & S & 2.73 \\
13 & M & 60 & S, T & 3.21 \\
14 & M & 25 & S, T & 4.54 \\
15 & M & 47 & S, B & 3.54 \\
16 & M & 52 & S, B & 3.40 \\
17 & F & 33 & S, B & 3.69 \\
18 & F & 36 & S, B & 3.00 \\
19 & M & 48 & S & 2.47 \\
20 & M & 23 & S, B & 4.57 \\
21 & S & 4.48 \\
\hline
\end{tabular}

S-salbutamol; B-beclomethasone dipropionate; $\mathrm{P}$-prednisone; I-ipratropium bromide; T-theophylline; F-fenoterol; C-sodium cromoglycate.

their maintenance treatment are shown in table 1.

Each subject visited the laboratory on two occasions within a period of two weeks, when possible at the same time of day. On one visit a methacholine inhalation test was performed $\left(M_{1}\right)$ and on the other occasion a methacholine inhalation test $\left(\mathrm{M}_{2}\right)$ followed a challenge with $\mathrm{UNH}_{2} \mathrm{O}$. This protocol was followed in patients $1-16$. In six patients $(17-22)$ histamine was substituted for methacholine.

Resting lung function and changes induced by the challenge procedures were monitored with a Cavitron spirometer (California USA), which measured forced expiratory volume in one second $\left(\mathrm{FEV}_{1}\right)$ and forced vital capacity (FVC). At the start of the methacholine or histamine inhalation challenge resting $F_{E V}$ and FVC were measured. Several forced expirations were performed, until reproducible values were obtained. Values for resting lung function were then expressed as a percentage of predicted values according to Morris et al. ${ }^{7}$

Two inhalations of a $0.9 \% \mathrm{w} / \mathrm{v}$ saline solution at room temperature were administered via a de Vilbiss No 40 hand held nebuliser. Patients inhaled from functional residual capacity towards total lung capacity, during which time the bulb of the nebuliser was squeezed by the operator. The patient held the breath for two to three seconds and then exhaled

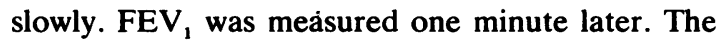
challenges were conducted in a manner similar to that described by Yan et al. ${ }^{\mathbf{8}}$ Histamine and methacholine solutions of $0.625 \%, 2.5 \%$ and $5 \%$ $\mathrm{w} / \mathrm{v}$ were prepared. Patients received initially one and then three inhalations of the $0.625 \%$ solution, three inhalations of the $2.5 \%$, and three inhalations of the $5 \%$ solution. When one dose consisted of more than one inhalation these were administered in consecutive breaths. The FEV 1 was measured one minute after each dose, and the highest of two or three measurements recorded. On the basis of previous reports on the output of the nebuliser and the concentration of the solution ${ }^{8}$ the delivered cumulative doses of methacholine were calculated to be $0.096,0.385,1.54$, and $6.12 \mu \mathrm{mol}$ for methacholine and $0.06,0.24,0.98$, and $3.9 \mu \mathrm{mol}$ for histamine. In one patient (No 16) the cumulative methacholine dose was increased to $13 \mu \mathrm{mol}$. The challenge was stopped when the FEV had fallen by more than $20 \%$ of the prechallenge, postsaline level. The dose of methacholine or histamine required to induce a $20 \%$ reduction in $\mathrm{FEV}_{1}\left(\mathrm{PD}_{20}\right)$ was determined by extrapolation from a curve constructed to relate change in $F E V_{1}$ to the cumulative dose of methacholine or histamine inhaled.

The $\mathrm{UNH}_{2} \mathrm{O}$ challenge was carried out with the $\mathrm{Mist}_{2}$ gen ultrasonic nebuliser EN 143A (California, USA), which delivered about $1 \mathrm{ml}$ of aerosolised water for each $10 \mathrm{l}$ of air inhaled. The technique used for $\mathrm{UNH}_{2} \mathrm{O}$ challenge has been described in detail. ${ }^{2}$ Before inhaling $\mathrm{UNH}_{2} \mathrm{O}$ and after measurement of resting $\mathrm{FEV}_{1}$ and $\mathrm{FVC}$ as above, the patient inhaled 401 of room air. No subject had a fall in $\mathrm{FEV}_{1}$ of $15 \%$ or greater from initial values after this preliminary test.

Initially the patient inhaled $0.5 \mathrm{ml}$ of aerosolised water. Thirty seconds later the $\mathrm{FEV}_{1}$ was measured and the highest of two or three estimations was recorded. If the fall in $\mathrm{FEV}_{1}$ was less than $10 \%$ the patient received doses of about $1,2,4,8,8$, and $8 \mathrm{ml}$ of water until the FEV, had fallen by $20 \%$ or a total of $31 \mathrm{ml}$ had been inhaled. If at any point the $F E V_{1}$ fell by $10 \%$ the challenge proceeded more slowlythat is, the increments were halved. The reduction in $\mathrm{FEV}_{1}$ was expressed as a percentage of the prechallenge post-room air value.

After the $\mathrm{UNH}_{2} \mathrm{O}$ challenge the patients were allowed to rest for $40-60$ minutes. At this time a second methacholine or histamine challenge test was performed and again the $\mathrm{PD}_{20}$ was estimated from the relationship between percentage fall in $F E V_{1}$ and dose of methacholine or histamine. The log of this $P_{20}$ was compared with the log of the $P_{20}$ from the first methacholine or histamine challenge by using Student's $\boldsymbol{t}$ test for correlated data. Analysis of variance was used to compare FEV, values before the three challenge tests. The significance of correlations was examined by means of least squares regression analysis. Results were considered significant when $\mathrm{p}<0.05$. 


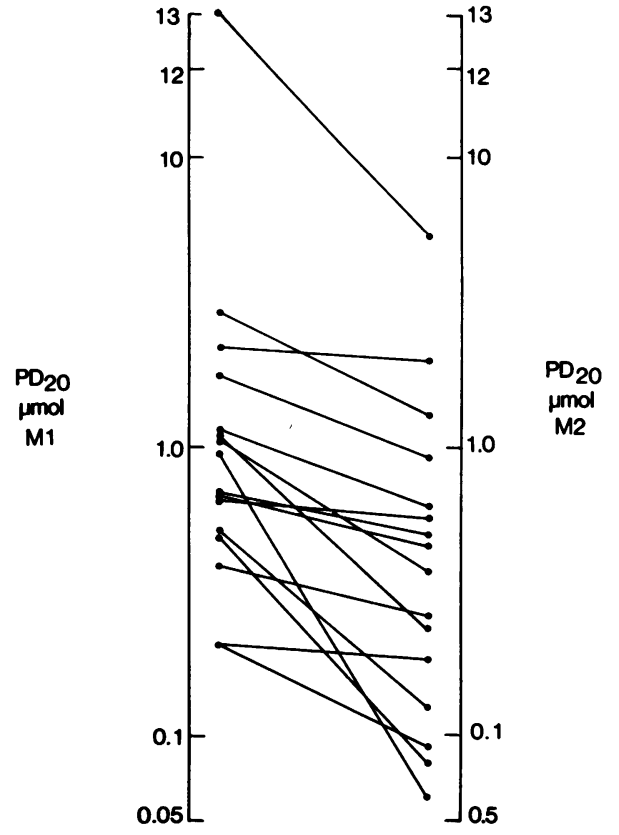

Fig 1 Dose of methacholine $\left(P D_{20}\right)$ required to produce a $20 \%$ fall in $F E V$, in the two methacholine challenges $\left(M_{1}\right.$ and $\left.M_{2}\right)$ in 16 patients.

\section{Results}

All patients showed a fall in $\mathrm{FEV}_{1}$ of more than $20 \%$ with both $M_{1}$ and $M_{2}$. The $F E V_{1}$ fell after $\mathrm{UNH}_{2} \mathrm{O}$ challenge by $18-40 \%$ (mean (SD) $30.5 \%$ $(6.7 \%))$. There was no significant difference for the group in the prechallenge $\mathrm{FEV}_{1}$ values expressed as a percentage of the predicted values before the two

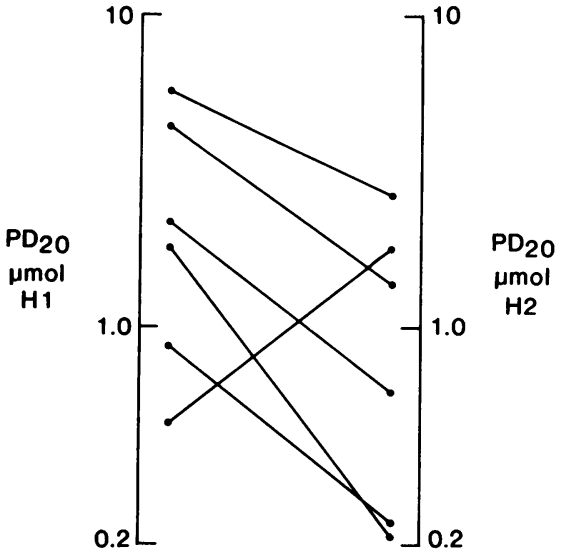

Fig 2 Dose of histamine $\left(P D_{20}\right)$ required to produce a $20 \%$ fall in $F E V_{1}$ in the two histamine challenges $\left(H_{1}\right.$ and $\mathrm{H}_{2}$ ) in six patients.

methacholine tests $\left(M_{1} 85 \%(16 \%)\right.$ and $M_{2} 80.8 \%$ $(16.3 \%))$ and before the $\mathrm{UNH}_{2} \mathrm{O}$ challenge $(90 \%$ (13\%)); but the latter value was significantly higher than that before $M_{2}(p<0.001)$. In all 16 patients the $\mathrm{PD}_{20}$ for $\mathrm{M}_{2}$ was lower than that for $\mathrm{M}_{1}$ (fig 1). The mean $\mathrm{PD}_{20}$ (95\% confidence limits) for the group was $0.9(0.5,1.6) \mu \mathrm{mol}$ for $\mathrm{M}_{1}$ and $0.4(0.2$, $0.8) \mu \mathrm{mol}$ for $\mathrm{M}_{2}$; these values are significantly different $(\mathrm{p}<0.001)$. Values for individual patients are shown in table 2 .

There was no significant correlation between the resting $F E V_{1}$ expressed as a percentage of predicted values and the $\mathrm{PD}_{20}$ for either $\mathrm{M}_{1}(\mathrm{r}=0.09, \mathrm{p}>$ $0.05)$ or $M_{2}(r=0.19, p>0.05)$ or between the actual $F E V_{1}$ values and the $\mathrm{PD}_{20}$. There was, how-

Table $2 F E V_{1}$ expressed as a percentage of predicted normal value (\% pred) before the first methacholine challenge $\left(M_{1}\right)$, before the second methacholine challenge $\left(M_{2}\right)$, and before the water challenge $\left(\mathrm{H}_{2} \mathrm{O}\right)$ and dose of provoking agent producing a $20 \%$ fall in $F E V_{1}\left(P D_{20}\right.$-shown in umol for $M_{1}$ and $M_{2}$ and in $\mathrm{ml}$ for $\left.\mathrm{H}_{2} \mathrm{O}\right)$

\begin{tabular}{|c|c|c|c|c|c|c|c|c|c|}
\hline \multirow{2}{*}{$\begin{array}{l}\text { Patient } \\
\text { No }\end{array}$} & \multicolumn{3}{|c|}{$F E V_{1}(\%$ pred $)$} & \multicolumn{3}{|c|}{$\%$ fall in $F E V_{1}$} & \multicolumn{3}{|l|}{$P D_{20}$} \\
\hline & $M_{1}$ & $\mathrm{H}_{2} \mathrm{O}$ & $M_{2}$ & $M_{1}$ & $\mathrm{H}_{2} \mathrm{O}$ & $M_{2}$ & $M_{1}$ & $\mathrm{H}_{2} \mathrm{O}$ & $M_{2}$ \\
\hline 1 & 81.6 & 89.7 & 69.1 & 42.5 & 34.4 & 37.3 & 0.40 & 1.47 & 0.27 \\
\hline 2 & 88.4 & 84.8 & 71.6 & 26.5 & 36.6 & 41.5 & 0.52 & 0.69 & 0.13 \\
\hline 3 & 88.3 & 109.8 & 88.0 & 26.4 & 29.1 & 39.1 & 0.65 & 14.56 & 0.61 \\
\hline 4 & 76.1 & 77.6 & 67.3 & 28.3 & 25.6 & 40.5 & 1.05 & 4.09 & 0.40 \\
\hline 5 & 75.7 & 85.9 & 79.2 & 61.6 & 36.8 & 55.6 & 0.21 & 0.51 & 0.20 \\
\hline 6 & 80.3 & 88.3 & 65.4 & 61.9 & 40.7 & 52.3 & 0.68 & 1.20 & 0.48 \\
\hline 7 & 101.5 & 107.3 & 102.9 & 41.1 & 38.6 & 43.1 & 0.22 & 0.75 & 0.09 \\
\hline 8 & 120.6 & 117.7 & 111.5 & 30.4 & 29.1 & 34.4 & 1.10 & 7.47 & 0.25 \\
\hline 9 & 63.3 & 73.8 & 60.8 & 44.7 & 34.4 & 47.3 & 0.50 & $<0.95$ & 0.08 \\
\hline 10 & 104.8 & 84.1 & 72.6 & 32.7 & 34.5 & 27.1 & 0.98 & $<0.75$ & 0.06 \\
\hline 11 & 51.5 & 65.3 & 64.4 & 26.0 & 23.0 & 34.0 & 0.70 & 3.70 & 0.52 \\
\hline 12 & 89.0 & 112.6 & 109.7 & 21.0 & 20.9 & 25.0 & 2.90 & 9.00 & 1.30 \\
\hline 13 & 98.9 & 102.6 & 95.0 & 28.0 & 26.0 & 44.0 & 2.18 & 4.00 & 2.05 \\
\hline 14 & 74.5 & 86.9 & 73.8 & 27.2 & 26.6 & 30.0 & 1.75 & 4.20 & 0.94 \\
\hline 15 & 89.2 & 82.6 & 84.4 & 24.7 & 19.0 & 23.5 & 1.15 & 3.30 & 0.64 \\
\hline 16 & 82.0 & 81.0 & 77.0 & 22.0 & 18.0 & 21.0 & 13.50 & 31.00 & 5.40 \\
\hline
\end{tabular}


Table $3 F E V_{1}$ expressed as a percentage of predicted normal value (\% pred) before the first histamine challenge $\left(H_{1}\right)$, before the second histamine challenge $\left(\mathrm{H}_{2}\right)$, and before the water challenge $\left(\mathrm{H}_{2} \mathrm{O}\right)$ and dose of provoking agent producing a $20 \%$ fall in $F E V_{1}\left(P D_{20}-\right.$ shown in umol for $H_{1}$ and $H_{2}$ and in $m l$ for $\left.H_{2} O\right)$

\begin{tabular}{|c|c|c|c|c|c|c|c|c|c|}
\hline \multirow{2}{*}{$\begin{array}{l}\text { Patient } \\
\text { No }\end{array}$} & \multicolumn{3}{|c|}{$F E V_{1}(\%$ pred $)$} & \multicolumn{3}{|c|}{$\%$ fall in $F E V_{1}$} & \multicolumn{3}{|l|}{$P D_{20}$} \\
\hline & $H_{1}$ & $\mathrm{H}_{2} \mathrm{O}$ & $\mathrm{H}_{2}$ & $H_{1}$ & $\mathrm{H}_{2} \mathrm{O}$ & $\mathrm{H}_{2}$ & $H_{1}$ & $\mathrm{H}_{2} \mathrm{O}$ & $\mathrm{H}_{2}$ \\
\hline $\begin{array}{l}17 \\
18 \\
19 \\
20 \\
21 \\
22\end{array}$ & $\begin{array}{r}70.0 \\
99.0 \\
77.0 \\
102.0 \\
99.0 \\
86.0\end{array}$ & $\begin{array}{l}66.8 \\
93.2 \\
85.0 \\
97.6 \\
94.5 \\
76.8\end{array}$ & $\begin{array}{l}61.0 \\
88.0 \\
83.7 \\
95.0 \\
85.0 \\
75.2\end{array}$ & $\begin{array}{l}20.0 \\
31.0 \\
20.0 \\
26.0 \\
29.0 \\
42.0\end{array}$ & $\begin{array}{l}21.0 \\
14.2 \\
22.0 \\
24.0 \\
16.0 \\
36.0\end{array}$ & $\begin{array}{l}41.0 \\
26.0 \\
22.0 \\
20.0 \\
28.0 \\
39.8\end{array}$ & $\begin{array}{l}0.50 \\
4.50 \\
1.80 \\
0.88 \\
5.80 \\
2.20\end{array}$ & $\begin{array}{r}0.95 \\
>31.50 \\
1.40 \\
1.20 \\
>31.50 \\
10.60\end{array}$ & $\begin{array}{l}1.80 \\
1.40 \\
0.22 \\
0.24 \\
2.75 \\
0.63\end{array}$ \\
\hline
\end{tabular}

ever, a significant correlation between the $\mathrm{PD}_{20}$ for $M_{1}$ and that for $M_{2}(r=0.8, p<0.001)$. The percentage fall in $\mathrm{FEV}_{1}$ in response to $\mathrm{UNH}_{2} \mathrm{O}$ correlated significantly with the $\mathrm{PD}_{20}$ for $\mathrm{M}_{2}(\mathrm{r}=0.8$, $\mathrm{p}<$ $0.001)$ and the $\mathrm{PD}_{20}$ for $\mathrm{M}_{1}(\mathrm{r}=0.8, \mathrm{p}<0.001)$. There was no significant correlation $(\mathrm{r}=0.2, \mathrm{p}>$ $0.05)$ between the percentage fall in response to $\mathrm{UNH}_{2} \mathrm{O}$ and the increased sensitivity to methacholine, nor was there a correlation $(r=0.4, p$ $>0.05$ ) between the percentage difference in $\mathrm{FEV}_{1}$ before the two methacholine challenges and the percentage difference in the $\mathrm{PD}_{20}$ values.

Of the six patients in whom sensitivity to histamine was studied, five were more sensitive to the histamine challenge performed after $\mathrm{UNH}_{2} \mathrm{O}$ challenge $\left(\mathrm{H}_{2}\right)$ than to the first histamine challenge $\left(\mathrm{H}_{1}\right)$ (fig 2). The $\mathrm{PD}_{20}$ to histamine in the remaining patient increased after $\mathrm{UNH}_{2} \mathrm{O}$ challenge from 0.5 $\mu \mathrm{mol}$ to $1.8 \mu \mathrm{mol}$. When the results for the six patients were analysed, there was no significant difference $(p>0.05)$ between the mean $P D_{20}$ values for $\mathrm{H}_{1}$ and $\mathrm{H}_{2}$. Individual values for the histamine study are shown in table 3 . All patients showed a fall in $\mathrm{FEV}_{1}$ in response to $\mathrm{UNH}_{2} \mathrm{O}$ challenge, ranging from $14 \%$ to $36 \%$ of the prechallenge level. All patients recovered to within $10 \%$ of prechallenge levels of $\mathrm{FEV}_{1}$ after $\mathrm{UNH}_{2} \mathrm{O}$ and before the commencement of $\mathrm{H}_{2}$. There was no significant difference between resting $F E V_{1}$ before the two histamine challenges $(p>0.05)$.

\section{Discussion}

This study has shown that patients with asthma have increased sensitivity to inhaled methacholine when it is administered after a challenge with $\mathrm{UNH}_{2} \mathrm{O}$. Moreover, this finding was not specific for methacholine as a similar result was obtained in a small group of patients in whom histamine was the provoking agonist. In some patients the decrease in $\mathrm{PD}_{20}$ with the second methacholine challenge was small, but the change in the $\mathrm{PD}_{20}$ was always in the same direction. There is no apparent explanation for the finding that patient 17 did not show an increased sensitivity to histamine.

The increased sensitivity to these agonists was not merely a reflection of increased airway tone after the $\mathrm{UNH}_{2} \mathrm{O}$ challenge. ${ }^{\prime \prime}$ Although the mean FEV , before the second methacholine challenge was significantly lower than that before the $\mathrm{UNH}_{2} \mathrm{O}$ challenge, there was no difference between the mean values for the starting airway calibre before the two methacholine challenges. In some patients the $F_{1} V_{1}$ was lower before $M_{2}$, but this was not a consistent finding. All patients, however, showed an increased sensitivity to methacholine after $\mathrm{UNH}_{2} \mathrm{O}$ challenge. Moreover, there was no correlation between the baseline lung function and the response to methacholine as determined by the $\mathrm{PD}_{20}$, or between the percentage difference in the $F E V_{1}$ before the two methacholine challenges and the percentage difference in $\mathrm{PD}_{20}$. Although the percentage fall in $\mathrm{FEV}_{1}$ after $\mathrm{UNH}_{2} \mathrm{O}$ correlated significantly with the $P_{20}$ for $M_{2}$ a correlation was also evident for $M_{1}$, implying that it related to the sensitivity to challenge rather than to a change in responsiveness. An increase in responsiveness is not universal with a second challenge-in fact, an appreciable decrease in responsiveness to repeated challenge with $\mathrm{UNH}_{2} \mathrm{O}$ performed $40-60$ minutes after the first challenge has been recorded. ${ }^{2}$ Hahn et al ${ }^{11}$ found that prior exercise challenge did not affect subsequent histamine reactivity, and others have reported $^{12}$ that methacholine reactivity was unaltered during the refractory period after exercise or hyperventilation induced asthma.

Our findings could result from inherent variability in the methacholine and histamine inhalation tests. Yan et $\mathrm{al}^{8}$ have found that when histamine inhalation tests are carried out on two separate days, the $\mathrm{PD}_{20} \mathrm{FEV}_{1}$ values are highly reproducible when a de Vilbiss nebuliser is used. There is no reason to suspect that findings with methacholine would be different, especially as asthmatic subjects show similar responsiveness to these two agonists. ${ }^{13}$ Again, the fact that an increase in responsiveness was found in 
21 of 22 patients would seem to diminish the importance of variability in our findings.

Differences in the time elapsed since the last bronchodilator treatment are unlikely to explain our results. This was kept constant for the two challenges. Although the four to six hour time interval may not have eliminated the influence of theophylline, this factor would have operated equally during $M_{1}$ and $M_{2}$ in these five patients.

The mechanism by which $\mathrm{UNH}_{2} \mathrm{O}$ challenge itself induces bronchoconstriction is not known. The fact that aerosols of hypertonic saline also induce asthma favours a change in osmotic environment of the airways as being important in the chain of events that leads to contraction of airway smooth muscle. There are several observations supporting the idea that mediators derived from mast cells play a part and that time is taken to replenish these. Thus the response to $\mathrm{UNH}_{2} \mathrm{O}$ is appreciably inhibited by sodium cromoglycate and patients have significantly less response to the same dose of $\mathrm{UNH}_{2} \mathrm{O} 40$ minutes after challenge. ${ }^{2}$ We have documented a considerable change in neutrophil chemotactic activity in asthmatics but not normal subjects ${ }^{5}$ in response to a challenge with $\mathrm{UNH}_{2} \mathrm{O}$. The potentiating effect of a water challenge on methacholine and histamine responsiveness may relate to the inflammatory changes brought about by the release of histamine and other substances from mucosal cells sensitive to changes in the osmotic environment. Mast cells release mediators in response to changes in osmolarity, although they are thought to be more sensitive to hyperosmolar than hypoosmolar challenges. ${ }^{14-17}$

An inflammatory response to the initial stimulus could account for the increase in non-specific bronchial responsiveness in this study. Holtzman et al ${ }^{18}$ have shown an association between inflammation and hyperresponsiveness in experiments carried out in dogs. Methacholine challenge tests were performed in dogs before and after exposure to ozone. In dogs showing an increased responsiveness to methacholine subsequent histological examination of the airways revealed an inflammatory response with recruitment of neutrophils. Moreover, those dogs that were not hyperresponsive showed no evidence of airway inflammation. The increase in methacholine responsiveness was apparent only one hour after ozone challenge, an interval similar to that in our study. Furthermore, activated complement fragments such as $\mathrm{C} 5 \mathrm{a}$ desarg have been shown to produce airway hyperresponsiveness in rabbits, ${ }^{6}$ again suggesting an association between airway inflammation and increased airway muscle responsiveness.

In the present study we were not able to investi- gate the duration of the increased airway responsiveness after $\mathrm{UNH}_{2} \mathrm{O}$ challenge. The studies with ozone in $\operatorname{dogs}^{18}$ have shown that the increased responsiveness to methacholine detectable one hour after ozone exposure is absent one week later. Further studies are necessary to determine whether the alteration in airway responsiveness induced by $\mathrm{UNH}_{2} \mathrm{O}$ challenge persists for longer than one to two hours.

The mechanism by which the inflammatory process augments airway reactivity is not apparent. It could arise from reflex stimuli resulting from a lowered threshold in nerve endings. It is possible that inflammatory mediators released from mast cells, from neutrophils themselves, or from airway epithelial cells "prime" the smooth muscle. Neutrophils are known to produce leukotrienes and these in turn are known to augment responses of airway smooth muscle to other agonists. ${ }^{19}$ Possibly the increase in airway responsiveness observed in the present study is the result of changes in epithelial permeability. Mediators released in response to $\mathrm{UNH}_{2} \mathrm{O}$ challenge may have altered airway epithelial permeability, thus allowing greater access to the histamine and cholinergic receptor sites of the smooth muscle. Exposure to cigarette smoke alters epithelial permeability and has been shown to result in increased responsiveness to histamine in guinea pigs. ${ }^{20}$ Demonstration of this, however, requires the presence of beta-adrenergic and parasympathetic antagonists. Others have shown that subjects who smoke exhibit increased permeability but not increased reactivity. ${ }^{21}$

Borland $e t a^{22}$ found a significant reduction in the clearance time for technetrium $99 \mathrm{~m}$ labelled DTPA after challenge with $\mathrm{UNH}_{2} \mathrm{O}$ but not with saline or cold air, which suggests that $\mathrm{UNH}_{2} \mathrm{O}$ results in an increase in permeability. Others have reported that osmotic gradients can lead to disruption and swelling of epithelial tight junctions. ${ }^{23-25}$

In conclusion, our study has shown that responsiveness to methacholine was increased after $\mathrm{UNH}_{2} \mathrm{O}$ challenge. This was not specific for methacholine as results were similar when histamine was the provoking agonist. Further studies are necessary to determine the mechanism underlying these findings.

We gratefully acknowledge the support of the National Health and Medical Research Council of Australia.

\section{References}

1 Schoeffel RE, Anderson SD, Altounyan REC. Bronchial hyperreactivity in response to inhalation of ultra- 
sonically nebulised solutions of distilled water and saline. $\mathrm{Br}$ Med J 1981;283:1285-7.

2 Anderson SD, Schoeffel RE, Finney M. Evaluation of ultrasonically nebulised solutions for provocation testing in patients with asthma. Thorax 1983;38:284-91.

3 Anderson SD, Schoeffel RE. A method for documenting bronchial hyperresponsiveness using ultrasonically nebulized water. Practical Cardiology 1984;10:69-88.

4 Lee TH, Nagy L, Nagakura T, Walport MJ, Kay AB. Identification and partial characterization of an exercise-induced neutrophil chemotactic factor in bronchial asthma. J Clin Invest 1982;69:889-99.

5 Shaw RJ, Anderson SD, Durham SR, Taylor KM, Schoeffel RE, Green W, Torzillo P, Kay AB Mediators of hypersensitivity and "fog"-induced asthma. Allergy 1985;40:48-57.

6 Irvin CG, Henson PM, Berend N. Acute effects of airways inflammation on airway function and reactivity. Fed Proc 1982;41:1358 (abstract).

7 Morris JF, Temple WP, Kosti A. Normal values for the ratio of one-second forced expiratory volume to forced vital capacity. Am Rev Respir Dis 1973;108:1000-3.

8 Yan K, Salome C, Woolcock AJ. Rapid method for measurement of bronchial responsiveness. Thorax 1983;38: 760-5.

9 Benson MK. Bronchial hyperreactivity. Br J Dis Chest 1975;69:227-39.

10 Tattersfield AE. Measurement of bronchial reactivity: a question of interpretation. Thorax 1981;36:561-5.

11 Hahn AG, Nogrady SG, Tumilty DMacA, Lawrence SR, Morton AR. Histamine reactivity during the refractory period after exercise induced asthma. Thorax 1984;39:919-23

12 Rosenthal RR, Laube BA, Hooper HH, Phillips Y, Herman PS. Methacholine sensitivity is unchanged during the refractory period following exercise or isocapnic challenge. $J$ Allergy Clin Immunol 1984;73:179 (abstract).

13 Salome CM, Schoeffel RE, Woolcock AJ. Comparison of bronchial reactivity to histamine and methacholine in asthmatics. Clin Allergy 1980;10:541-6.

14 Kaliner M, Austen KF. Cyclic AMP, ATP and reversed anaphylactic histamine release from rat mast cells. J Immunol 1974; 112:664-74.

15 Findlay SR, Lichtenstein LM. Basophil "releasability" in patients with asthma. Am Rev Respir Dis 1980;122:53-9.

16 Eggleston P, Sobotka AK, Schleimer R, Lichtenstein LM. Interaction between hyperosmolar and IgE mediated histamine release from basophils and mast cells. Am Rev Respir Dis 1984;13:86-91.

17 Day RO, Wade DN. Effect of various drugs on the osmotic lysis of rat mast cells. Clin Exp Physiol Pharmacol 1978;5:477-85.

18 Holtzman MJ, Fabbri LM, O’Byrne PM, et al. Importance of airway inflammation for hyperresponsiveness induced by ozone. Am Rev Respir Dis 1983;127:68690.

19 Creese BR, Bach MK. Hyperreactivity of airways smooth muscle produced in vitro by leukotrienes. Prostaglandins, Leukotrienes and Medicine 1983;11:161-9.

20 Hulbert WC, McLean T, Pare PD, Hogg JC. The relationship between cigarette smoke-induced airway inflammation and histamine reactivity in guinea pigs. $J$ Clin Invest Med 1983;6, suppl 1:76 (abstract).

21 Kennedy SM, Pare PD, Elwood RK, Wiggs B, Hogg JC. Lung epithelial permeability and airway reactivity in smokers and non-smokers. Am Rev Respir Dis 1983;127: 252 (abstract).

22 Borland C, Chamberlain A, Minty B, Royston D, Higenbottam $T$. Lung epithelial permeability changes after breathing a fine mist of distilled water but not after breathing cold air. Thorax 1983;38:221 (abstract).

23 DiBona DR, Civan MM. Intracellular pathways for water and solute across the toad bladder. In: Transport mechanisms of epithelium. Symposium V. Munksgaard, Copenhagen, 1973.

24 Wade JB, Karnovsky MJ. Fracture faces of osmotically disrupted zonulae occludentes. J Cell Biol 1974; 62:344.

25 Hunpert F, Grondshuys A, Pricom C, Perrelet A, Orci L. Morphological changes in tight junctions of $\mathrm{Nec}$ turus maculosus proximal tubules undergoing saline divisions. J Cell Biol 1976;69:90. 